\title{
INTER PARTES REVIEW AND THE DESIGN OF Post-Grant Patent REVIEWS
}

\author{
Colleen Chien ${ }^{\dagger}$, Christian Helmers ${ }^{\dagger+}$ \& Alfred Spigarellitt
}

\begin{abstract}
Inter partes review (IPR) is one of several mechanisms for vetting patents after they have been granted. While the purpose of IPRs is to provide a cheaper, more expert alternative to litigation for screening out bad patents, the devil is in the design details. For example, the inclusion of key procedural features in IPRs, such as fixed time frames and expanded discovery contributed to making it far more popular than its predecessors. As the United States weighs additional changes to the administration of IPRs, including expanding the basis for amendment and unifying standards of review, it is worth considering the experiences of the European Patent Office (EPO) and Germany with their parallel opposition and nullification (revocation) procedures. This Article compares and contrasts U.S. IPR, EPO opposition, and German revocation actions and explores what they suggest, collectively, about the optimal design of post-grant review systems.

Despite heightened concerns in the United States about IPR invalidation rates, outcomes are comparable across the three venues: $81 \%$ of reviewed claims and $26 \%$ of claims challenged in U.S. IPR proceedings are cancelled; $68 \%$ of patents reviewed and $63 \%$ of patents challenged in EPO opposition proceedings are amended or canceled; and $73 \%$ of the patents reviewed and $28 \%$ of the patents challenged in German revocation proceedings are partially or fully invalidated. But seemingly slight differences have contributed to the distinct roles each proceeding plays in its domestic patent system. The relative slowness of German infringement actions has translated into a parallel district action stay rate of $10-15 \%$, as compared to an $80 \%$ stay rate among U.S. district court litigations that proceed in parallel to the IPR. Patentees also have fewer rights in U.S. IPRs than they do in EPO opposition proceedings, but have substantial rights to amend and can expect consolidated challenges. Focusing on how small

DOI: https://doi.org/10.15779/Z38B56D49T

(C) 2019 Colleen Chien, Christian Helmers \& Alfred Spigarelli.

† Professor of Law at Santa Clara University Law School, Justin D’Atri Visiting Professor of Law, Business, and Society, Columbia Law School.

H Associate Professor at Leavey School of Business at Santa Clara University.

H+ Of Counsel at Santarelli law firm and former Director of the EPO. We thank Brian Love, Shawn Ambwani of Unified Patents, Fabian Gaessler, Yassine Lefouili, and Eleanor Yost of Goodwin Proctor for sharing data and insights about U.S. and German post-grant systems with us, and Patrick Wu, Hannah Jian, David Schwartz, Mark Lemley, and participants at the Berkeley Administrative Law Conference and Stanford IPR Conference-Academic Day for their comments and assistance with earlier drafts. We welcome feedback at colleenchien@gmail.com, christian.r.helmers@gmail.com, and alfred.spigarelli@gmail.com. All errors are ours.
\end{abstract}


differences have had big impacts on procedural and substantive outcomes, this Article discusses the implications of features such as the ability to amend and pre-institution decisions on the design and efficacy of post-grant patent reviews. 


\section{TABLE OF CONTENTS}

I. INTRODUCTION 819

II. AN OVERVIEW OF POST-GRANT PATENT REVIEWS IN THE PTO, AT THE EPO, AND AT THE GERMAN DPMA ...........825

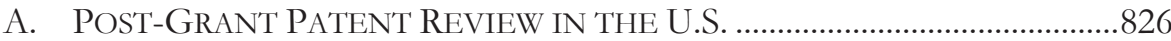

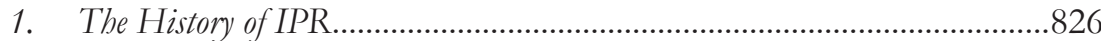

2. PGR (First Window Review) ....................................................................827

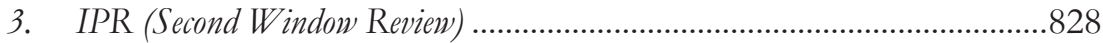

4. "Life of the Patent" Reviews ………………………………………….........829

B. IN THE EUROPEAN PATENT OFFICE ..........................................................829

1. Opposition (First Window Review) ...........................................................829

2. Limitation and Revocation ("Life of the Patent") Reviews .............................833

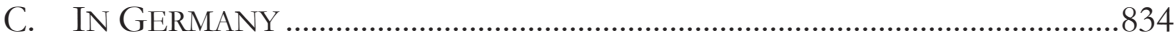

1. German Opposition ("First Window"), Limitation, and Nullity

(Revocation) ("Life of the Patent") Reviews ...................................................834

2. Nullity ("Second Window”) Reviews.........................................................835

III. SELECT FEATURES OF POST-GRANT PATENT REVIEW .........838

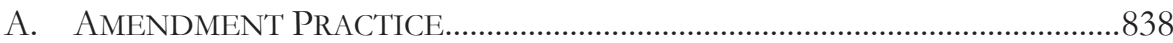

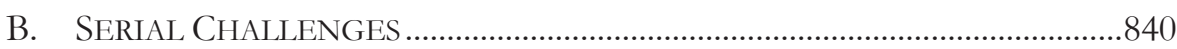

C. CLAIM CONSTRUCTION STANDARDS ................................................................840

D. COORDINATION BETWEEN INFRINGEMENT AND INVALIDITY

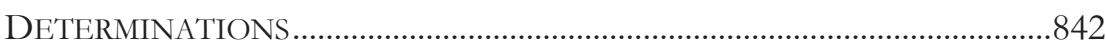

IV. U.S. (IPR), EUROPEAN (OPPOSITION) AND GERMAN (BPATG) SUBSTANTIVE AND PERFORMANCE-RELATED

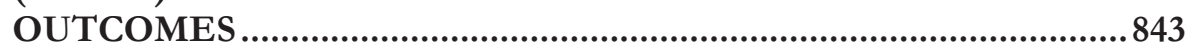

A. INVALIDITY RATES AND RATES OF ADJUDICATION ………………..........844

B. TIME TO A MERITS-DECISION.........................................................................847

C. BIFURCATION-RELATED OUTCOMES ……..................................................848

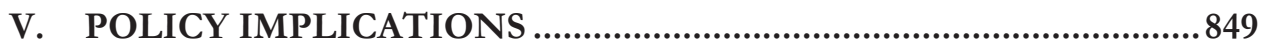

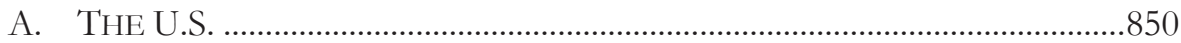

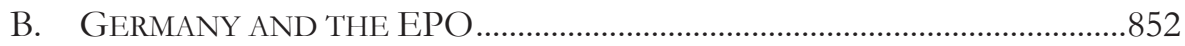

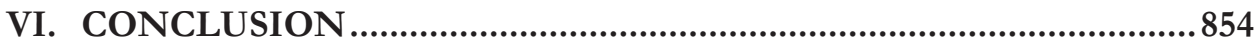

\section{INTRODUCTION}

Although only a patent office can grant a patent, patents can be taken away in multiple venues and multiple ways. In the United States, a patent's invalidity is typically raised as a defense to a claim of infringement made in a district court or at the International Trade Commission. But increasingly, parties are 
turning back to the agency that issued the patent in the first place- the United States Patent Office (PTO) — to revisit its validity. The PTO offers several advantages over district court for doing so. Post-grant patent reviews (a term we use to refer to all post-grant review processes including IPR, PGR, CBM, and reexam) support correction of the patent regardless of whether or not there is a case or controversy, ${ }^{1}$ they allow generalist juries and judges to avoid thorny technical and legal question, and they support cheaper, more expert adjudication. $^{2}$ As Congress described when it created several administrative trial proceedings through the Leahy-Smith America Invents Act (AIA), such post-grant proceedings are intended to provide "quick and cost effective alternatives to litigation." 3

But whether or not administrative proceedings are actually faster and less expensive than litigation for evaluating the validity of patents depends on how the proceedings are implemented. At best, inter partes review (IPR) and related proceedings substitute for litigation-based validity adjudication by eliminating the need for it; for example, when a patent is fully invalidated by an IPR or a patentee's position is fully or even partially vindicated driving settlement. But these proceedings may also complement or supplement, rather than substitute for parallel proceedings, introducing additional costs, complexities, and delays. This can happen when, for example, the court does not stay co-pending litigation, the IPR fails to substantially clarify the status of the patent, or the patent is subject to multiple serial challenges, each introducing additional delays and complications.

Whether a particular post-grant patent review operates in practice more like a substitute or complement to litigation depends on how it is administered and implemented. While post-grant patent reviews are often discussed in general terms, each form of post-grant review has its own unique purpose and set of procedures. For example, opposition proceedings at the European Patent Office (EPO) and U.S. post-grant review (PGR) procedures are available for the first nine months after the patent is granted ("first window"), ${ }^{4}$

1. The source of the error may stem from a change in the law (e.g., a new decision which calls into question the validity of a patent that was valid when issued), a change in the facts (e.g., a new piece of prior art not considered by the patent office), or patent office error.

2. See, e.g., Joseph Farrell \& Robert P. Merges, Incentives to Challenge and Defend Patents: Why Litigation Won't Reliably Fix Patent Office Errors and Why Administrative Patent Review Might Help, 19 Berkeley TECH. L.J. 943 (2004); Bronwyn H. Hall et al., Prospects for Improving U.S. Patent Quality via Post-Grant Opposition (Nat'l Bureau of Econ. Research, Working Paper No. 9731, 2003); Bronwyn H. Hall \& Dietmar Harhoff, Post-Grant Reviews in the U.S. Patent System - Design Choices and Expect Impact, 19 BERKELEY TECH. L.J. 989 (2004).

3. H.R. Rep. No. 112-98, pt. 1, at 48 (2011), as reprinted in 2011 U.S.C.C.A.N. 67, 78; see also id. at 40 (AIA "is designed to establish a more efficient and streamlined patent system that will improve patent quality and limit unnecessary and counterproductive litigation costs").

4. European Patent Convention art. 99(1), Nov. 29, 2001, 1065 U.N.T.S. 284 
other proceedings are only available after this initial period, during the "second window," and still others are available throughout a patent's life. ${ }^{5}$ While some proceedings, such as IPRs, can be initiated by parties other than the patentee, others, such as European limitation and revocation proceedings ${ }^{6}$ and American reissue proceedings can only be initiated by the patentee. Only American reissue proceedings permit the patentee to enlarge, not diminish, the patent's scope, at least in the first two years of the patent's life. ${ }^{7}$

Table 1: Forms of Post-Grant Patent Reviews

\begin{tabular}{|l|l|l|l|}
\hline Timing & US $^{8}$ & EPO & Germany \\
\hline "First" Window9 & Post-Grant Review (PGR) & Opposition & Opposition \\
\hline $\begin{array}{l}\text { "Second" } \\
\text { Window" }\end{array}$ & $\begin{array}{l}\text { Inter Partes Review (IPR), } \\
\text { Covered Busines Method } \\
\text { Review (CBM) }\end{array}$ & None & $\begin{array}{l}\text { Nullity } \\
\text { (revocation) } \\
\text { actions }\end{array}$ \\
\hline Life of the Patent & Reissue, Ex Parte Reexam & $\begin{array}{l}\text { Revocation, } \\
\text { Limitation }^{14}\end{array}$ & None \\
\hline
\end{tabular}

[hereinafter EPC].

5. See infra tbl.1.

6. See, e.g., European Patent Office, Guidelines for Examination, Guidelines FOR OpPosition and Limitation/Revocation Procedures, https://www.epo.org/law-practice/legal-texts/html/guidelines/e/d_x_1.htm [https://perma.cc/2QDB-LSKZ] [hereinafter EPO EXAMINATION GUIDELINES].

7. American reissue proceedings that broaden the patent may only be initiated within the first two years of the patent's life. See 35 U.S.C. $\$ 251$ (d).

8. For a description of various U.S. post grant patent review proceedings, see generally, Joe Matal, A Guide to the Legislative History of the America Invents Act: Part II of II, 21 FED. CIR. B.J. 539 (2012).

9. The "first window" represents the time frame within the first nine months after a patent is granted.

10. EPC art. 99.

11. For an overview of Germany opposition system, see Opposition Systems, WIPO, https://www.wipo.int/scp/en/revocation_mechanisms/opposition/index.html [https://perma.cc/M37S-64H4] (last visited, Jan. 24, 2019).

12. The "second window" represents the time frame any time after the first window.

13. Nullity or "revocation" proceedings are heard by a court, not the patent office. However, the scope of review is limited to the patent's validity. See infra Part II.

14. EPC art. 105a. 
When passing the AIA in 2011, Congress focused on the importance of design choices by ushering in three new forms of post-grant patent review: PGR, covered business method (CBM) Review, and IPR. ${ }^{15}$ The most popular of these, IPR, improved upon its predecessor, inter partes reexamination, by introducing a strict schedule, conditions that made it favorable for courts to stay their parallel cases, and evidentiary guidelines. ${ }^{16}$ These small changes have made a big difference in the uptake of post-grant review: while the PTO received fifty-three requests in the first five years of inter partes reexamination, ${ }^{17}$ the Patent Trial and Appeal Board (PTAB) received 7,930 requests in the first five years of IPR (from September 2012 to December 2017). ${ }^{18}$

But in addition to being popular, IPR processes have also been controversial, principally because they have resulted in the cancellation of a large share of the claims that the PTO has fully reviewed. By February 2018, $65 \%$ of final decisions in IPR proceedings concluded that all reviewed claims were unpatentable, and 16\% concluded that some reviewed claims were unpatentable, resulting in an $81 \%$ rate of partial or total invalidity. ${ }^{19}$

The high rate of invalidity and resulting outcry ${ }^{20}$ has prompted a reconsideration of how IPR is administered. In 2017, the Federal Circuit's Aqua Products decision made it easier for patentees, in certain cases, to amend their patents during IPR. ${ }^{21}$ In 2018, the PTO changed the legal standard for

15. For an overview, see, e.g., Matal, supra note 8, at 623 (2012).

16. Id.

17. Id. at n. 379 (citing the 2011 Committee Report for the ALA, H.R. Rep. No. 198, at 46, 48 (2011)) (reporting that the USPTO received fifty-three requests for inter partes reexam in the first five years of the proceeding).

18. U.S. Patent \& Trademark Office, Trial Statistics, IPR, PGR, CBM, Patent TRIAL AND APPEAL BOARD, DECEMBER 2017, https://www.uspto.gov/sites/default/files/ documents/Trial_Statistics_2017-12-31.pdf [https://perma.cc/K6GD-X2RF].

19. U.S. Patent \& Trademark Office, Trial Statistics, IPR, PGR, CBM, Patent Trial and Appeal BoArd, February 2018 [hereinafter PTAB February Statistics] https://www.uspto.gov/sites/default/files/documents/trial_statistics_20180228.pdf [https://perma.cc/HT9A-MAMR]; see Brian J. Love \& Shawn Ambwani, Inter Partes Review: An Early Look at the Numbers, 81 U. CHI. L. REV. DiALOGUE 93, 94 (2014) (reporting a 77\% cancellation rate based on the first few years of the program).

20. See, e.g., Rochelle Cooper Dreyfuss, Giving the Federal Circuit a Run for its Money: Challenging Patents in the PTAB, 91 NOTRE DAME L. REV. 235, 251 (2015) (describing critics who believe that the IPR outcomes suggest that PTAB is "out of control").

21. Aqua Products, Inc. v. Matal, 872 F.3d 1290, 1296 (Fed. Cir. 2017) (finding that petitioners have the "burden of persuasion with respect to the patentability of amended claims" in IRP proceedings, rather than the patentee). The court further held that "the Board must consider the entirety of the record before it when assessing the patentability of amended claims under $\int 318(\mathrm{a})$ and must justify any conclusions of unpatentability with respect to amended claims based on that record." Id. 
claim interpretation during IPRs to make it consistent with the standard applied in litigation ${ }^{22}$ and moved to explore expansion of the ability of patentees as well as to amend their claims during the post grant review process ${ }^{23}$ including "the institution decision, and the conduct of hearings." 24 These developments make it timely to consider other post-grant systems that have been around for longer and, in some cases, have years of experience implementing features being considered by the PTO.

This Article compares and contrasts three forms of post-grant patent review: U.S. IPR, EPO opposition proceedings, and German nullification, considering their processes, outcomes, and, collectively, what they imply about the optimal design of post-grant patent reviews. The European opposition system has been around for decades, making it a natural point of comparison. ${ }^{25}$ Further, the availability of data about the European opposition system supports a nuanced understanding of how it is carried out in practice. German revocation or "nullification" proceedings provide another useful point of comparison because, like IPR, nullification is "second window" review that takes place after the first nine months of the patent's life, and often proceeds in parallel with, but independently from, a court's evaluation of infringement. This raises unique issues with respect to the interplay between the courts and the IPR system.

This Article finds that, although attracting a lot of attention, IPR outcomes are not far outside the norms among other post-grant patent review systems. $81 \%$ of final written decisions in IPR proceedings partially or fully invalidate the patent, ${ }^{26}$ while more than the $68 \%$ of patents reviewed in EPO opposition $^{27}$ and $73 \%$ of patents reviewed in German revocation proceedings,

22. See PTAB Issues Claim Construction Final Rule, U.S. PAT. \& Trademark OfF., https://www.uspto.gov/patents-application-process/patent-trial-and-appeal-board/

procedures/ptab-issues-claim-construction [https://perma.cc/AY29-2CF9] (last visited Jan. 24, 2019).

23. See PTAB Seeks Comments on Proposed Changes to Motion to Amend Practice in AIA Trials, U.S. PAT. \& TRADEMARK OFF., https://www.uspto.gov/patents-application-process/patenttrial-and-appeal-board/resources/ptab-mta-rfc [https://perma.cc/J36M-XBEF] (last visited Jan. 24, 2019) [hereinafter PTAB Changes to Motion to Amend].

24. Andrei Iancu, Director, U.S. Patent \& Trademark Office, Statement before the House Committee on the Judiciary, (May 22, 2018).

25. European opposition has been available since the 1970s. See EPC art. 19.

26. It should be noted that a single patent can be subject to multiple petitions. Thus, these figures, as reported by the USPTO, are really at the petition, rather than the patent, level.

27. These are numbers from 2017. From 2011 to 2014, about 33\% were maintained in amended form and 39\% were revoked. In 2015 and 2016, 69\% of the opposed patents were partially or totally invalidated with still more revocation than amended patents. A switch took place in 2017 with a larger rate of amended patents than revoked patents. Author analysis based on EPO figures in consultation with EPO officials. 
which are available after the opposition window has closed, are also partially or fully invalidated. ${ }^{28}$ However, only the U.S. IPR system requires challenges to survive a pre-institution filter. This inflates the invalidation rate in the U.S. because many patents that are challenged are never fully reviewed. When all challenged (rather than reviewed) patents are considered, U.S. IPR invalidation rates shrink relative to other venues: $26 \%$ of patents challenged in U.S. IPRs, $63 \%$ of patents challenged in the EPO, and $28 \%$ of the patents challenged in German revocation proceedings are partially or fully invalidated. ${ }^{29}$

But differences in procedures have led to differences in outcomes. The relative speed and predictability of the U.S. IPR system stands in contrast to the other venues, particularly German nullity actions, which take place in court but at a pace that does not match German infringement actions. ${ }^{30}$ As a result, only about $10-15 \%$ of German infringement proceedings are stayed, ${ }^{31}$ as compared to a partial or full stay rate of $82 \%$ in U.S. district court proceedings in which a stay motion was filed and there is a pending, instituted parallel IPR. ${ }^{32}$ Partly as a result of the low stay rate in Germany, 12\% of the injunctions awarded in Germany rely on patents that are later invalidated. ${ }^{33}$ Patentees also have fewer rights in U.S. IPRs than they do in EPO opposition proceedings, where patentees can more liberally amend their claims and expect a consolidated, single challenge, rather than be subject to serial challenges. ${ }^{34}$

Part II describes the purpose of inter partes post-grant reviews and discusses the major categories of post-grant patent reviews in the PTO, EPO, and Germany, with a particular focus on U.S. IPR, EPO opposition proceedings, and German nullity proceedings. Part III delves deeper into several aspects of review that are the subject of recent policy interest: amendments, serial petitions, claim construction standards, and the

\section{See infra fig.4.}

29. See id.

30. See generally Cremers et al., Invalid but Infringed? An Analysis of the Bifurcated Patent Litigation System, 131 J. ECON. BEHAV. \& ORG. 218 (2016) (describing how German invalidity and opposition proceedings take significantly longer than infringement proceedings).

31. See Jochen Herr \& Marc Grunwald, Speedy Patent Infringement Proceedings in Germany: Pros and Cons of the Go-To Courts, 7 J. InTELL. Prop. L. \& PRAC. 44, 44 (2012).

32. The rate for IPRs filed between September 2012 and December 2016 was calculated using data provided by Unified Patents and MaxVal. We calculated the stay rate at the caselevel between "parallel cases," defined as district court cases and IPR petitions that satisfied the following criteria: (a) the same patent is asserted in court and challenged in an IPR, (b) the plaintiff in the IPR petition is the defendant in the district court infringement case, and (c) the IPR petition was filed within 12 months of the court filing date. Only instituted IPRs are considered to compute the stay rate. Note that the stay rate for all parallel cases regardless of whether a motion for a stay was filed is slightly less than $40 \%$.

33. Cremers et al., supra note 30, at 219.

34. See id.; see also PTAB Changes to Motion to Amend, supra note 23. 
coordination in the "second window" of invalidity and infringement proceedings. Part IV considers the outcomes associated with key design choices and evaluates the extent to which, based on outcome data, it appears that post-grant patent reviews are playing their intended, substitutionary role. Part V discusses policy implications, and Part VI concludes.

\section{AN OVERVIEW OF POST-GRANT PATENT REVIEWS IN THE PTO, AT THE EPO, AND AT THE GERMAN DPMA}

While the public benefits when an improperly issued patent is invalidated-in the form of greater freedom to innovate and greater competition, for example-the defendant solely bears the high costs of attempting to invalidate a patent in court. For this reason, patent invalidation can be thought of as a public good that is at risk of underproduction. ${ }^{35}$ Further, only a minority of issued patents are contested and worth the extra scrutiny. ${ }^{36}$

Depending on how they are implemented, post-grant patent reviews can address both the public goods nature of invalidity challenges as well as the sorting problem associated with the large skew in the value of patents. The cost of invalidating a patent in post-grant patent review not only can be substantially less than the cost of invalidating it in court, but can also be shared by all whose freedom of action would increase upon the patent's invalidity. ${ }^{37}$ By occurring later in a patent's life, after its value has been established, postgrant patent reviews also support the application of extra scrutiny to the patents that actually matter.

For these reasons, a well-functioning post-grant patent review process is an important component of a healthy patent system. As discussed below, though the process began in the early 2000s, it was not until the AIA of 2011 that the current U.S. regime of post-grant patent reviews, featuring IPR (which replaced inter partes reexamination proceedings), CBM, and PGR, were put in place. In contrast, European opposition proceedings have existed since the EPO's formation in the early 1970s. ${ }^{38}$

After briefly discussing the events leading to IPR's creation, this Section summarizes the post-grant patent review mechanisms of the United States,

35. See Farrell \& Merges, supra note 2, at 952.

36. Colleen V. Chien, Predicting Patent Litigation, 90 TEx. L. REV. 283, 287(2011) (noting that only $1-2 \%$ of patents are litigated).

37. See Dreyfuss, supra note 20, at 284-85 (describing the work of RPX and Unified Patents, who pool the resources of their members to initiate IPRs).

38. EPC art. 99. There was not much discussion about the need to introduce opposition as from the beginning in the EPC because opposition was a traditional feature of most patent systems in Europe. See M. VAN EMPEL, ThE Granting of EuropeAn PATENTS point 461 (1975). 
Europe, and Germany, with a focus on three main mechanisms of interest: U.S. IPRs, European opposition proceedings, and German nullity actions. U.S. IPR's success and efficient administration hold lessons both for the German nullity and EPO opposition proceedings for whom, as described below, timing has presented a challenge.

The more mature European system can also serve as a reference point for the U.S. IPR as it experiences growing pains.. While some credit IPRs as being the most impactful intervention for reducing patent trolling, ${ }^{39}$ the change has also been abrupt, leading many in the community to feel the dismay that Supreme Court Justice Neil Gorsuch expressed in his dissent in Oil States v. Greene:

After much hard work and no little investment you devise something you think truly novel. Then you endure the further cost and effort of applying for a patent .... At the end of it all, the Patent Office agrees your invention is novel and issues a patent.... But ... someone later emerges from the woodwork, arguing that it was all a mistake and your patent should be canceled[.] ${ }^{40}$

As the sections below describe, each post-grant patent review process is unique. Key differences include timing and duration (when review is offered, and how long it takes); who can initiate and participate in the process (inter partes proceedings involve third parties other than the patentee, whereas ex parte proceedings are between the patentee and patent office only); and whether or not the reviews are meant to proceed in parallel with litigation (thereby providing a "bifurcated" system), or whether infringement and invalidity are meant to be decided together (in a "unified" system). These and other key differences are summarized at the end of this Section in Table 2.

\section{A. Post-Grant Patent Review in the U.S.}

\section{The History of IPR}

In the early 2000s, the perception that the PTO was improperly issuing large numbers of patents led a powerful coalition of stakeholders, including the PTO, National Academies of Sciences, the American Intellectual Property Law Association, and the Biotechnology Industry Organization, to endorse the creation of "an effective, efficient post-grant system to review patents" 41

39. See, e.g., Colleen Chien, Panel Discussion at the South by Southwest Conference: The Persistence of Patent Trolls in Tech (Mar. 12, 2018) (presenting the results of a small survey, $\mathrm{N}=90$ that, in response to a question about the impact of certain interventions to reducing the threat of patent trolls, ranked IPR first (with a score of 4.3 out of 5), followed by 101 caselaw (4.2), TC Heartland (3.4), CBM (3.3), fee-shifting (2.7) and Form 18 (2.3)).

40. Oil States Energy Servs., LLC v. Greene’s Energy Grp., 138 S. Ct. 1365, 1380 (2018) (Gorsuch, J., dissenting).

41. Patent Quality Improvement: Post-Grant Opposition: Hearing before the Subcomm. on Courts, the 
within the United States. ${ }^{42}$ Then-existing inter partes reexaminations and other mechanisms for carrying out post-grant review were perceived as underused and burdensome to the PTO, ${ }^{43}$ because they often had a three- to five-year pendency. ${ }^{44}$

From this general desire for a cheaper way to weed out low-quality patents, the specific contours of a new set of reviews emerged through the congressional process. Early draft bills would have limited the period of postgrant review to nine months after issuance. However, the high-technology sector's concerns that this window was too short, given the time needed for a patent's value to emerge, led to the development of "life-of-the-patent" review proposals. ${ }^{45}$ The final compromise reflected an "all of the above" approach. Following passage of the AIA, the PTO now offers post-grant reviews (PGR) of patents during the "first window," nine months after patent issuance. ${ }^{46}$ While any basis of patentability can be challenged under PGR, PGR applies only to patents filed after March 15, 2013, and the number of patents challenged under PGR remains low. ${ }^{47}$ IPRs, which replaced inter partes reexamination proceedings, as well as CBM reviews, are available at any time following the initial nine-month period, or during the "second window." In SAS Institute v. Iancu, the Supreme Court determined that the PTAB cannot partially institute a petition for an IPR but must consider all claims brought before it, ${ }^{49}$ leading the PTAB to extend its review as to "all claims or none."

\section{PGR (First Window Review)}

PGRs are validity proceedings at the PTO that are available during the nine months after a patent's issuance or reissuance. ${ }^{51}$ They can be initiated by anyone but the patent owner on any grounds of patentability except for the

Internet, and Intellectual Prop. of the H. Comm. on the Judiciary, 108th Cong. 29-30 (2004) (statement of Michael Kirk, Executive Director, AIPLA); Matal, supra note 8, at 600 n.383.

42. See Matal, supra note 8, at 582 .

43. Id. at $600-05$.

44. Id. at $603-04,622$.

45. Id. at 601-02.

46. See 35 U.S.C. $₫ 321$ (2012).

47 47. PTAB FEBRUARY StATISTICS, supra note 19, at 5 (showing that 98 PGRs were filed from $9 / 16 / 12$ to $2 / 28 / 18)$.

48. See supra tbl.1.

49. See SAS Institute Inc. v. Iancu, 138 S. Ct. 1348, 1354 (2018) (holding that the agency lacks the authority to render partial judgments on petitions that challenge issued patent).

50. Shortly after SAS Institute Inc. v. Iancu, the USPTO issued guidelines ending its practice of partially instituting its decision. See U.S. PATENT \& Trademark OfFICE, GuidANCE ON THE IMPACT OF SAS ON AIA TRIAL PROCEedings (2018), https://www.uspto.gov/patents-application-process/patent-trial-and-appeal-board/trials/ guidance-impact-sas-aia-trial [https://perma.cc/WJ8E-6BSM].

51. 35 U.S.C. $\int 321$. 
"best mode" requirement, which requires that a patent applicant disclose the best way they know of making the invention, by the time of filing. ${ }^{52}$ The process begins when the challenger submits a petition to the PTO which then proceeds to a review by a three-judge panel of the Patent Trial and Appeals Board (PTAB). A PGR is instituted only if the panel is convinced, based on the petition, that it is "more likely than not" that at least one of the claims challenged in the petition is unpatentable. Assuming the parties do not settle, the Board will proceed to a final decision and determine whether the challenged claims are invalid or should be upheld. Accordingly, there are four possible merit outcomes associated with a PGR: institution denied, all claims upheld, some claims upheld, or all claims invalidated.

Importantly, decided PGRs have preclusive effects on related district court and International Trade Commission (ITC) litigation, meaning that the challenger (and associated real parties in interest) cannot later argue that any claim subject to a final written decision is invalid on any grounds that the petitioner "raised or reasonably could have raised during that PGR." 53 Additionally, the U.S. "first window" procedures proceed on strict timelines, completing twelve to eighteen months after institution. ${ }^{54}$ This stands in contrast with EPO "first window" reviews, known as oppositions, which currently take around two years on average. However, the EPO aims to reduce the duration to fifteen months by $2020 .{ }^{55}$ Because PGR is currently available only for patents with an effective filing date (priority) on or after March 16, 2013, and it takes several years for a patent to be granted, uptake of PGR proceedings so far has been limited. From September 2012 through February 2018, only 98 PGR petitions have been filed. ${ }^{56}$

\section{IPR (Second Window Review)}

IPR, the primary form of "second window" review in the United States, is available to challenge all utility patents. Like PGR, inter partes reviews are initiated by third parties (not the patent owner), decided by a three-judge panel at the PTAB, and support the same four possible merit-based outcomes. However, in contrast to PGR's expansive bases for challenge, IPRs can only address anticipation or obviousness, based solely on patents and printed

52. 35 U.S.C. $\int 112(a)$.

53. 35 U.S.C. $\int 325(\mathrm{e})$.

54. See 35 U.S.C. $₫ 316$ (a)(11).

55. See Bronwyn H. Hall et al., supra note 2; Improving Timeliness, EUROPEAN PATENT OFF., https://www.epo.org/about-us/annual-reports-statistics/annual-report/2016/ highlights/improving-timeliness.html [https://perma.cc/W76Z-7U4F] (last visited Jan. 24, 2019) ("By 2020 the EPO aims to cut the overall duration of our opposition procedure for straightforward cases to within 15 months.").

56. PTAB FEBRUARY STATISTICS, supra note 19 , at 3. 
publications..$^{57}$

Fig. 1: IPR Timeline

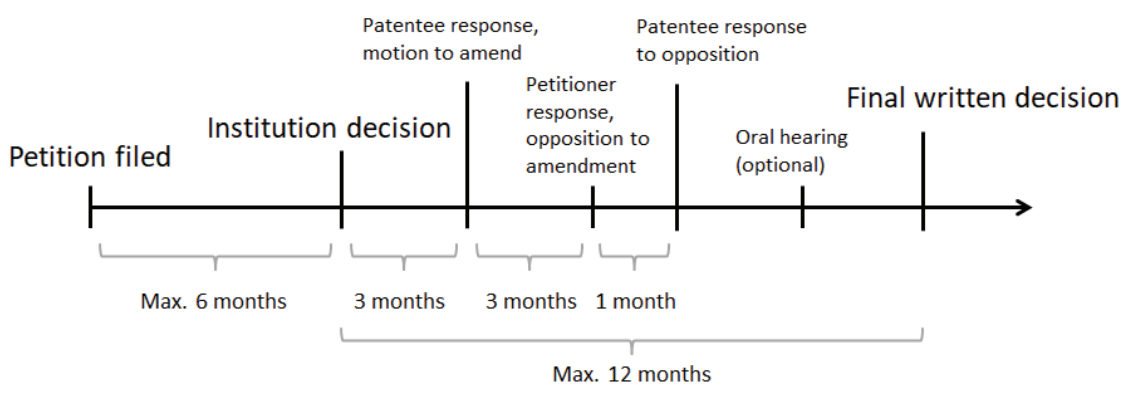

Like PGR, IPR begins with a petition to the PTO that requests review of the contested patent. ${ }^{58}$ This request must be filed within one year of any parallel litigation ${ }^{59}$ and will only be granted if the petitioner shows that there is a reasonable likelihood of prevailing on at least one claim challenged in the petition. ${ }^{60}$ Once instituted, a final determination on the validity of the claims must be completed within twelve months unless the PTO extends the period of review by up to six months. ${ }^{61}$ The district court judge can grant a stay of the infringement proceedings while a PTAB challenge is pending. The stay of the infringement proceedings assumes a crucial role in avoiding situations where the patent is found "invalid but infringed."

\section{4. "Life of the Patent" Reviews}

In addition to the new AIA PTAB trial proceedings, preexisting ex parte reexamination and reissue proceedings remain available anytime over the life of the patent. ${ }^{62}$ U.S. district courts and the ITC can also hear validity challenges alongside infringement claims.

B. In the European Patent Office

1. Opposition (First Window Review)

Since its formation in the 1970s, the EPO has offered opposition proceedings ${ }^{63}$ to third parties seeking to clarify the status of granted patents

57. See 35 U.S.C. \311(b) (AIA \6).

58. See supra fig.1.

59. See 35 U.S.C. $\$ 315(\mathrm{~b})$ (AIA \6).

60. See 35 U.S.C. $\$ 314(\mathrm{a})$ (AIA $\$$ 6).

61. See 35 U.S.C. \$\316(a)(11), 318(a) (AIA \$6).

62. See infra tbl.1.

63. See EPC art. 99. Opposition has been a traditional feature of most patent systems in 
within the first nine months of the patent's life. Each "EPO patent" must be perfected in all the member states designated by the applicant ${ }^{64}$ before it can be enforced-there is no such thing as an enforceable "European patent." Therefore, after expiration of the "first window," validity challenges, with the exception of limitation and revocation, are heard only in front of the relevant national authority. Because there is not yet any "second window" for challenging an EPO patent, ${ }^{65}$ this raises the stakes and the incentive to challenge patents during the first window.

Article 100(a)-(c) of the EPC lays out the grounds of opposition at the EPO, which are wide-ranging and include the major patentability criteria ${ }^{66}$ except for "clarity," which is equivalent to the definiteness requirement in the United States. Unlike U.S. IPR, there is no formal institution stage in EPO opposition. Moreover, the EPO permits the patentee to amend challenged patents, leading to three possible merit outcomes: rejection of the opposition (confirmation of all claims), ${ }^{67}$ complete revocation of all claims, and maintenance of the patent in an "amended form." outcome: closure of the opposition without a decision on the patent validity. For example, the opposition can be withdrawn before the opposition division decides to proceed on its own motion on the basis of its prima facie opinion on the patent validity, the facts, and submissions submitted by the opponent. ${ }^{69}$ For some time, the merit outcomes of oppositions at the EPO have been described as "three-thirds": with one-third of opposed patents maintained as granted, one-third were amended, and one-third revoked. ${ }^{70}$

Europe, but there was not much discussion about the need to introduce opposition from the beginning in the EPC. See M. VAn Empel, The Granting of European Patents (European Aspects) point 461 (1975).

64. On average EP patents are validated in four member states. The most frequently designated member states are Germany, UK, France, Italy, and the Netherlands.

65. This may change when the Unitary Patent Protection enters into force. See generally The Select CommitTeE \& THE Preparatory CommitTeE of THE Unified PATENT Court, An ENHANCED European PATENT SySTEM (2014).

66. See EPC art. 100(a) (the subject matter is not patentable because it is not an invention according to the EPO and it does not meet the other three patentability criteria: novelty, inventive step, and industrial applicability); see also id. at art. 100(b) (the disclosure of the invention is not sufficient to enable somebody skilled in the art to practice the invention); $i d$. at art. 100(c) (the subject matter of the European patent amended in such a way that it extends beyond the content of the application as filed).

67. See European Patent Office, Guidelines for Examination, D-III, $\int 1.3$.

68. See, e.g., Stuart J.H. Graham \& Dietmar Harhoff, Separating Patent Wheat from Chaff: Would the U.S. Benefit from Adopting Patent Post-Grant Review?, 43 REs. POL'Y 1649, 1651 (2014). Other options include rejection of the opposition with the patent maintained as granted, and closure of the opposition without a decision on the patent validity.

69. See id. at $1653-55$.

70. From 1980-2000, about $22 \%$ of opposed patents were upheld entirely, $35 \%$ were 
At the EPO, the Opposition Division carries out opposition proceedings according to two main principles. First, the opposition division must ensure that it has communicated its opinion to the parties before it can take a decision. ${ }^{71}$ Second, the patentee has the right to amend the opposed patent, subject to the approval of the Opposition Division. However, an opposed patent can only be amended when this is justified by at least one of the opposition grounds. For example, if the opponent objects to a lack of novelty on a particular claim, only that particular claim can be amended by the patentee, with the condition that the Opposition Division consider that the corresponding objection is potentially jeopardizing the patentability of that claim. In other words, a weak objection against a claim is not sufficient to justify amendment. Moreover, the amendments will need to be restricted to what is necessary for retaining patentability (further details provided in Part III). ${ }^{72}$

The proceedings take place as follows (see Fig. 2): ${ }^{73}$ during the "first window" (the nine months following publication of the decision to grant a European patent in the European Patent Bulletin), any person can file an opposition request. ${ }^{74}$ The opposition request must specify the grounds on which the opposition is being filed, namely, either that the invention is not described sufficiently clearly for it to be carried out by a person of skill; that the subject matter of the patent either extends beyond the content of the application as filed; ${ }^{75}$ or some other grounds. The notice of opposition is

revoked entirely, and the remainder, about $43 \%$, were upheld with amendment. About $8 \%$ of European patents were opposed, with process engineering and chemistry patents challenged most frequently. In the 2000s, a smaller share of patents, around 5\% from 2000-2014, were opposed, with around $28 \%$ of opposed patents being upheld without amendment. In 2015 and 2016, the opposition rate dropped to $4 \%$, and then to $3 \%$ in 2017 with the proportion of completely revoked patents dropping in parallel from around $40 \%$ to $34 \%$ in 2017 . However, from 2015 to 2017, the rate of patents at least partially invalidated remained stable at around $72 \%$.

71. The only exception is when it can decide on the sole grounds of opposition and argumentation that the opponent filed in the notice of opposition and the patentee has not asked for the benefit of oral proceedings. A corollary right to the right to be heard is the right of the parties to have oral proceedings.

72. Implementing Regulations to the Convention on the Grant of European Patents, Oct. 5, 1973, R.80, https://www.epo.org/law-practice/legal-texts/html/epc/2016/e/ r80.html [https://perma.cc/WQ97-SXYS] [hereinafter EPC Implementing Regulations].

73. See European Patent Office, Notice from the EPO Concerning the Opposition Procedure as from 1 July 2016, OJ 2016, A42.

74. EPC art. 99(1). Since the Enlarged Board of Appeal decided Hartdegen, Emmerich Ing. v. INDUPACK AG, G 3/97, (OJ 1999, 245) the EPO accepts opposition filed by a straw man as long as this is not used for circumventing the law. DERK VISSER, THE ANNOTATED European PATENT CONFERENCE (25th ed. 2017) (Art. 99, comment 1.2).

75. See EPC art. 100(b); see also supra note 66 and accompanying text. 
transmitted without delay to the patentee, and its formal admissibility is examined in parallel. However, the process really only begins at the end of the nine-month opposition period. The first deadline, the patentee's submission of amendments and arguments in response to the notice of opposition, is set four months after the end of the aforementioned opposition period. While the patentee isn't strictly required to submit amendments and arguments, practically speaking, the submission positions the patentee to preserve or defend the patent, and the submission often comprises a mix of arguments refuting the opponent's arguments and amendments for overcoming them. Some patentees file a main request asking for the patent to be preserved as granted and also to present different levels of amendments.

The Opposition Division begins substantial examination upon receipt of the patentee's response, which is also submitted to the opponent(s). Importantly, because of the limited period for filing oppositions, all oppositions received by the EPO within the nine-month period are consolidated into a single proceeding in which the patentee and all the opponents will be parties. Parties can request that witnesses be heard by the division. Afterwards, the opposition division issues its first office action, which is usually a summons to the oral proceedings. In the summons to the oral proceedings, the division indicates its provisional opinion on the claims' validity and the relevance of opposing grounds and related arguments in order to allow the parties to prepare for oral proceedings. The division then sets a deadline before the date of the oral proceedings for filing additional submissions. During the oral proceedings, the chairman of the division pronounces the decision of the division, which closes the procedure. If the EPO decides to maintain the patent in the amended form, the procedure continues, to allow the patentee to handle the required amendment formalities. $^{76}$

76. An assumed infringer may also intervene during an opposition procedure and become a new party to the pending opposition procedure. See EPC art. 105. 
Fig. 2: European Opposition Timeline

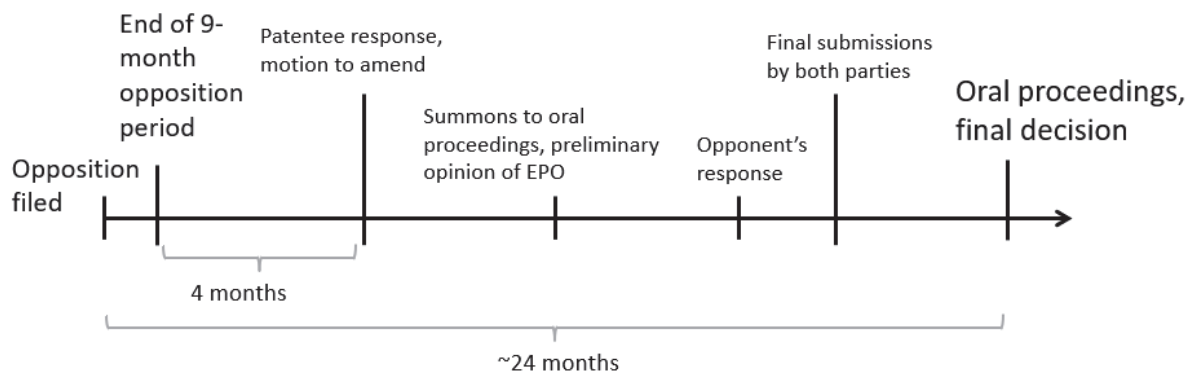

As described earlier, there is no "second window" of post-grant patent reviews in Europe, in part because infringement cases are dealt with exclusively at a national level. However, the future introduction of the United Patent Court (UPC) may change this. ${ }^{77}$

\section{Limitation and Revocation ("Life of the Patent") Reviews}

Although the EPO does not offer "second window" reviews, the patentee can initiate two additional types of post-grant reviews, limitation and revocation, ${ }^{78}$ at any time in the patent's life. The EPO introduced these two procedural options in the European Patent Convention 2000. ${ }^{79}$ The amendments were made to compensate for the absence of a central mechanism for enabling the patentee to modify his patent once granted, since the decision of the Enlarged Board of Appeal G 9/93 banned selfopposition. ${ }^{80}$ When an opposition is filed while a revocation request is pending, the revocation request will take precedence, since the patentee's revocation obviates the need for opposition. However, when an opposition is filed while a limitation proceeding is pending, the limitation proceeding will be terminated. ${ }^{81}$ If an opposition proceeding is pending, requests for limitations or revocations are denied. ${ }^{82}$ This means that a patent proprietor fearing that an opposition may be filed in the future can preemptively limit the scope of his or her patent (through limitation) or, at any time, request the patent's revocation, rendering future opposition superfluous or meaningless.

77. According to the Unified Patent Court Agreement, the UPC will be qualified to hear both infringement and invalidation arguments. Potential conflicts may arise between opposition at the EPO and early referral to the UPC because the UPC is not obliged to stay its proceedings until the opposition procedure at EPO is completed. See PIETER CALLENS \& SAM Granata, The Unitary Patent AND the Unified PATENT Court (2017).

78. See EPC art. 105a.

79. See id.

80. See VISSER, supra note 74, at 258.

81. See EPC Implementing Regulations, supra note 72, at R.93.

82. See id. 
As expected when introduced, the revocation procedure is seldom used by patentees. Patentees only filed a total of nine revocation requests in $2017 .^{83}$ In part this is because it is simpler to surrender a patent just by stopping payment of annual fees. To make a more visible pronouoncement, through revocation, and therefore clear one's path of unenforceable patents one can file a request without justification. Revocation requests will be immediately granted as long as the formal requirements are met and the corresponding fee paid.

Limitations are more popular than revocations, but, with only 55 requests in 2017, not much more. There is no requirement that patentees provide a reason for supporting a limitation request. Therefore, a limitation request can be strategically filed by patentees to tailor claim scopes to cover competitor products or market needs. This has earned them the reputation of being unfair weapons of patentees because third parties do not have any similar way of challenging patents throughout Europe.

The "clarification" that takes place as a result of limitation or any other cosmetic changes are, in theory, different from opposition. ${ }^{84}$ However, the line between clarity and patentability, in practice, is almost indistinguishable. Moreover, contrary to opposition proceedings, limitations are an ex parte procedure and the patentee need only contend with the examiner, not any third parties.

\section{IN GERMANY}

1. German Opposition ("First Window"), Limitation, and Nullity (Revocation) ("Life of the Patent") Reviews

Much like the EPO, the German Patent and Trademark Office (DPMA) offers opposition proceedings for challenging German patents in the "first window." ${ }^{85}$ Under the German Patent Act (Patentgesetz), a challenger can file a notice of opposition at the DPMA within the first nine months of a patent's life. ${ }^{86}$ Although the patentee cannot oppose his or her own patent, he or she may file for limitation or revocation of the patent during the patent's life, as in the European Union. ${ }^{87}$ However, unlike at the EPO, at the DPMA the patentee must explain or justify his request, for example, by providing the prior art that makes the limitation necessary. ${ }^{88}$

83. Source on file with authors.

84. VISSER, supra note 74, at 256 (Art. 105a, general comments).

85. See Cremers et al., supra note 30, app. A.

86. Id.

87. Patentgesetz [Patent Act], Dec. 16, 1980, BGBL I at 3830, last amended Oct. 19, 2013, 』 64 (Ger.).

88. Id. 


\section{Nullity ("Second Window") Reviews}

Following the "first window," the validity of a German patent can only be vetted through ("nullity") proceedings at the German Federal Patent Court (Bundespatentgericht-BPatG). ${ }^{89}$ Though an invalidity action can be filed by any entity, ${ }^{90}$ almost all invalidity actions, like IPRs in the United States, ${ }^{91}$ are filed in response to infringement claims. ${ }^{92}$ Nullity evaluations proceed independently of infringement evaluations, which are heard by twelve regional courts (Landgerichte, or, LG).$^{93}$ For nullity cases that involve litigated patents, the mandatory separation between claims for infringement and invalidity in Germany creates a "bifurcated" review system that defines many aspects of nullity reviews. ${ }^{94}$

The proceedings must be initiated at the BPatG, separate from the German regional court in which infringement is being decided. Not only are nullity actions heard in a separate venue, but the presumption of validity, the claim construction standard, and the timing of nullity actions also stand in contrast to German regional courts. For example, regional courts rely on a strong presumption of validity when hearing infringement cases. Further, parties are free to make conflicting arguments in each venue-infringement and invalidity courts - about the meaning of the claims. This is because the task before the infringement court is what the patent's scope of protection is, while the BPatG scrutinizes whether the patent satisfies statutory requirements for patentability. ${ }^{95}$ This creates an incentive for the patent owner to make a broad claim interpretation at a regional court while relying on a narrower claim

89. Cremers et al., Patent Litigation in Europe, 44 Eur. J.L. \& ECON. 1 (2017). Opposition proceedings can be filed at the DPMA within three months after grant and at the EPO within nine months after grant. An important distinction between opposition procedures at the DPMA and EPO and invalidity actions at the BPatG is that the patent offices can proceed ex officio with the opposition procedures even after the opponent has withdrawn the action.

90. Patentgesetz $\int 81$.

91. David Ruschie \& Scotot R. Boalick, Patent Public Advisory CommitTee Quarterly Meeting, PTAB Update 8 (Nov. 9, 2017), https://www.uspto.gov/sites/ default/files/documents/20171109_PPAC_PTAB_Update.pdf [https://perma.cc/3AJ7YYYX].

92. See Cremers et al., supra note 30, app. A n.49 (citing ANNE VON HEES \& SVEN-ERIK Braitmayer, Verfahrenscrecht in PATEntsachen (Carl Heymanns Verlag, 4th ed., 2010), who estimate that this is the case for $90 \%$ of all invalidity actions).

93. Unpublished manuscript on file with authors.

94. Unpublished manuscript on file with authors.

95. This is distinct from the U.S. process where the doctrine of prosecution history estoppel prevents patentees from arguing one way in front of the PTAB and another in district court. See Grober v. Mako Prods., 686 F.3d 1335, 1342 (Fed. Cir. 2012) (citing Abbott Labs. v. Sandoz, Inc., 566 F.3d 1282, 1289 (Fed. Cir. 2009)). 
construction at the BPatG. ${ }^{96}$ The timing is also not coordinated between the two venues. Sometime after an infringement action is filed (at the regional court), the invalidity challenge will be filed (at the BPatG). The infringement action, in the absence of a stay, proceeds, and, assuming the judgement is favorable for the patentee, results in an injunction. While invalidity proceedings take around twenty-four months to complete (see Fig. 3), infringement proceedings move faster, resolving in a median of nine months. In many cases, however, invalidity is still being decided at the BPatG, with one practitioner noting that while "infringement actions may be complete in a year, nullity actions can take two years."

Fig. 3: Nullity Proceedings at German BPatG

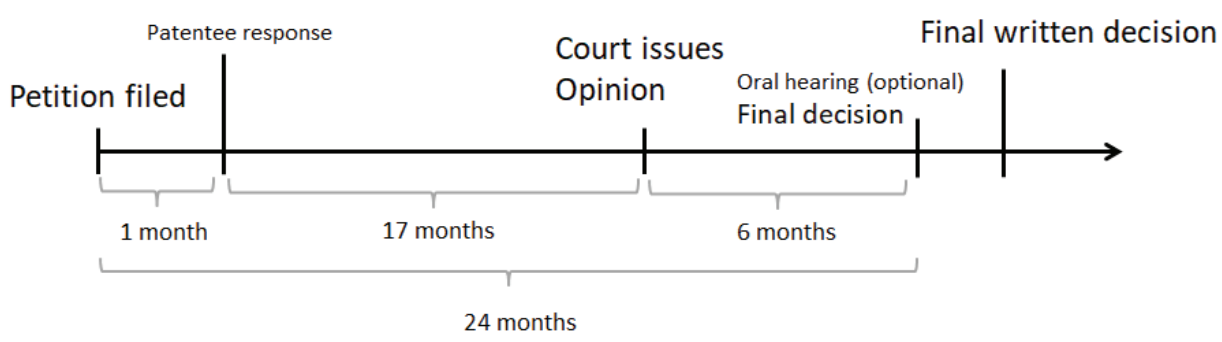

96. See infra Section III.C.

97. Keker \& VAN Nest LlP, Comparative Patent Litigation 8, https://www.law.berkeley.edu/wp-content/uploads/2015/09/06-Comparative-PatentLitigation-Germany-Versus-The-US.pdf [https://perma.cc/EU6N-TM3M] (last visited July 1, 2018); see Cremers et al., supra note 30, at 219. 
Table 2: Differences and Similarities between U.S. IPR, EPO Opposition Proceedings, and DPMA Nullification Systems ${ }^{98}$

\begin{tabular}{|c|c|c|c|}
\hline Feature & US IPR System & German BPatG & EPO Opposition \\
\hline Who May Bring & \multicolumn{3}{|l|}{ Any Third Party } \\
\hline When & Second Window & Second Window & First Window \\
\hline $\begin{array}{l}\text { Other Validity } \\
\text { Venues }\end{array}$ & Courts, ITC, PTO & None & Country courts \\
\hline $\begin{array}{l}\text { Institution } \\
\text { Threshold }\end{array}$ & $\begin{array}{l}\text { "Reas. likelihood" } \\
\text { of invalidity of } 1+ \\
\text { claim }\end{array}$ & None & None \\
\hline Parallel Litigation & $85 \%{ }^{99}$ & $90 \%$ & Not applicable \\
\hline Timing & $\begin{array}{l}12-18 \text { months on } \\
\text { average }\end{array}$ & $\begin{array}{l}24 \text { months on } \\
\text { average }\end{array}$ & $\begin{array}{l}\sim 24 \text { months on } \\
\text { average }^{100}\end{array}$ \\
\hline Costs & $\sim \$ 275 \mathrm{~K}$ per side ${ }^{101}$ & $€ 40 \mathrm{~K}-240 \mathrm{~K}^{102}$ & $€ 40 \mathrm{~K}^{103}$ \\
\hline Stay Rate & $82 \%$ & $10-15 \%$ & Not applicable \\
\hline Validity & \multicolumn{3}{|l|}{ Not presumed } \\
\hline $\begin{array}{l}\text { Claim } \\
\text { Construction }\end{array}$ & Same $e^{104}$ & Same ${ }^{105}$ & Same ${ }^{106}$ \\
\hline
\end{tabular}

98. For U.S. facts, see Love \& Ambwani, supra note 19, at app. B, unless otherwise noted; for German facts, see Cremers et al., supra note 3031. The description of EPO Opposition is based on the description provided on the EPO website unless otherwise noted. See Oppositions, EUR. PAT. OFF., https://www.epo.org/applying/european/oppositions.html [https://perma.cc/6PAB-Z22S] (last visited Jan. 24, 2019).

99. RusCHKE ET. AL., supra note 91, at 8.

100. See, e.g., Olga A. Partington \& Paul A. Calvo, A Comparison of US and EPO Post Grant Practices, LEXOLOGY (June 16, 2017), https://www.lexology.com/library/ detail.aspx?g=bd361876-a09d-4e55-99f6-afa30dc9cabb [https://perma.cc/SKB7-SQW3] (describing a range of 15-24 months; in our experience the average is much closer to 24 months).

101. Am. Intell. Prop. L. Ass’N, 2015 Report of the Economic Survey 43 (2015).

102. The data assumes value of claim from $€ 500,000$ to $€ 5$ million.

103. This is an estimate for a "simple" case. Correspondence with European attorney (on file with the authors).

104. See PTAB Issues Claim Construction Final Rule, U.S. PAT. \& Trademark OfF., https://www.uspto.gov/patents-application-process/patent-trial-and-appeal-

board/procedures/ptab-issues-claim-construction [https://perma.cc/9FLB-LX9V] (last visited Jan. 24, 2019) [hereinafter PTAB Claim Construction Final Rule] (describing the adoption of the Phillips claim construction standard used in litigation in IPR).

105. See EPO ExAmination Guidelines, supra note 6, at pt. F ch. IV (specifying that claim terms should be given "the meaning and scope which they normally have in the relevant art" unless the specification defines terms otherwise).

106. Broadest reasonable interpretation, in case of diverging opinion, the description can 


\begin{tabular}{|l|l|l|l|}
\hline Feature & US IPR System & German BPatG & EPO Opposition \\
\hline $\begin{array}{l}\text { same or different } \\
\text { than prosecution? }\end{array}$ & \multicolumn{2}{|l|}{} \\
\hline Reviewers, Nature & \multicolumn{2}{|l|}{ Expert (technically trained), inter partes } \\
\hline Proceedings & Oral hearings, expert witnesses & $\begin{array}{l}\text { Oral hearings, } \\
\text { witness possible } \\
\text { upon request }\end{array}$ \\
\hline Ability to Amend & Limited & Yes & Yes \\
\hline
\end{tabular}

\section{SELECT FEATURES OF POST-GRANT PATENT REVIEW}

Building on the last section's overview of post-grant reviews in several jurisdictions, this Section compares and contrasts a few of the salient features of European opposition, German nullification, and U.S. inter partes review. It focuses on aspects of post-grant patent review that are controversial in one or another jurisdiction. Because our hypothesis is that small administrative changes can have a big impact, this Part focuses on both large and small details in the administration of post-grant patents.

The first feature we discuss, the ability of the patentees to amend their patent, is well-integrated into EPO opposition proceedings (and theoretically available during German nullity proceedings as well), and is currently under development in the United States. Next, we address an area of controversy in the United States, how serial petitions are dealt with, with a focus on the consolidation of disputes in EPO opposition proceedings. Finally, we compare and contrast how German nullity and U.S. IPR "second window" processes approach two separate but related issues: claim construction and coordination (or lack thereof) in validity proceedings and infringement courts.

\section{A. AmENDMENT PRACTICE}

Though a patent owner has the statutory right to file a motion to amend or cancel a challenged patent claim and propose a reasonable number of substitute claims, in practice making amendments has been challenging for the holders of patents challenged in IPR proceedings. ${ }^{107}$ Responsive to concerns about amendment practice, the PTAB has carried out yearly studies on

be used to construe the claims. However, in principle claims must be clear on their own.

107. See Letter from Philip S. Johnson, President, Intellectual Prop. Owners Ass'n, to Michelle K. Lee, Director of the U.S. Patent \& Trademark Office [hereinafter Johnson Letter] (Oct. 20, 2015) (on file with author), http://www.ipo.org/wp-content/uploads/2015/10/ IPO-Comments-to-PTO-re-AIA-Trials-10-16-15.pdf [https://perma.cc/QC2L-AFAG]. 
motions to amend within IPR and related AIA proceedings (including CBM and PGR, whose numbers have been dwarfed among AIA proceedings, by IPR to date). ${ }^{108}$ According to the PTAB's calculations, through September 30, 2017, only $10 \%$ of completed trials included a motion to amend, and of those the PTAB decided the motion in $62 \%$ of the cases. Of those, only $4.2 \%$, or $\sim 7$ motions to amend, have been fully granted. ${ }^{109}$ As mentioned at the outset of this Article, Director Iancu of the PTO has indicated that amendments are one of several areas that the Patent Office is considering revising. ${ }^{110}$

At the EPO, one of the main guiding principles of opposition is that the patentee has the right to amend his or her patent when necessary. This occurs principally when justified by at least one ground of opposition, even when not objected to by an opponent. ${ }^{111}$ Procedurally speaking, the patentee's first opportunity to file amendments with the EPO lasts until four months after the "first window" has closed. ${ }^{112}$ The amendment must overcome a deficiency in the patent covered by at least one of the opposition grounds. ${ }^{113}$ When reviewing this information, the opposition division will first decide whether it is justified to file any amendments in light of the grounds of opposition. ${ }^{114}$ For example, if it finds that the patent as granted is not susceptible to invalidation on any grounds of opposition invoked by the opponents, the EPO will not consider any amendments. If, however, the division decides to consider the amendments, it will evaluate the patent as amended and determine whether or not it meet all the requirements of the invention.

In German nullity proceedings, the patentee retains a similar right to amend, though not to expand the patent's scope. According to Section 22 (1) of the German Patent Act, the patent will be revoked should the patent be amended in ways that impermissibly extend the scope of protection. ${ }^{115}$

108. See U.S. Patent \& Trademark Office, Patent Trial and Appeal Board Motion TO AMEnd STUDy (updated through Sept. 30, 2017), https://www.uspto.gov/ sites/default/files/documents/PTAB $\% 20$ MTA $\% 20$ Study $\% 20 \% 203 \% 20 \% 20$ update $\% 20$ thro ugh\%2020170930.pdf [https://perma.cc/GP68-RAUG].

109. Id. at 4-6.

110. Andrei Iancu, Dir., U.S. Patent \& Trademark Office, Statement before the House Committee on the Judiciary (May 22, 2018), https://www.uspto.gov/about-us/newsupdates/statement-director-andrei-iancu-committee-judiciary-0 [https://perma.cc/UGF4XLMT].

111. EPC IMPLEMENTING REgulations, supra note 72, at R.81(3).

112. Source on file with authors.

113. Source on file with authors.

114. Source on file with authors.

115. Patentgesetz [Patent Act], Dec. 16, 1980, BGBL I at 3830, last amended Oct. 19, 2013, 』22(1) (Ger.). 


\section{B. SERIAL CHALLENGES}

Another area in which there has been "a fair amount of controversy," in the words of then-interim PTO director Joe Matal, pertains to serial inter partes review (IPR) petitions. ${ }^{116}$ As the Intellectual Property Owners Association explains, there is a risk that serial petitions can be a tool for harassment ${ }^{117}$ and wearing down the patentee, albeit at a cost of filing multiple petitions. Currently, about $30 \%$ of challenged patents are subject to more than one IPR petition. ${ }^{118}$

In the EPO, all timely filed oppositions (in the nine-month first window) are handled by a formality officer supporting the opposition division. ${ }^{119}$ Upon receiving the notice of a subsequent opposition, the officer transmits the opposition notice without delay to the patentee and the other opponents, if any. ${ }^{120}$ Then, the officer examines whether the filed opposition meets the formal requirements of the EPC. ${ }^{121}$ After expiration of the nine-month opposition period, the formalities officer will send a communication to the patentee setting a four-month time limit for replying to all of the opposition notices received challenging the same patent to this date. ${ }^{122}$ The opposition division will become active only after receipt of the patentee's reply. ${ }^{123}$ Because most oppositions are filed relatively close to the end of the nine-month opposition period, the delay induced by this serial processing is largely counterbalanced by the positive aspects of grouping all oppositions in one single opposition procedure. ${ }^{124}$ Even after the nine months expire, any alleged infringer can join a pending opposition procedure. ${ }^{125}$

\section{Claim COnstruction Standards}

An additional contested aspect of IPRs concerns what claim construction standard should be used. The separation of infringement and invalidity proceedings presents opportunities to construe claims differently in different proceedings. A broad patent claim construction when claiming infringement

116. Transcript, Public Patent Advisory Committee (PPAC) Meeting 13 (Aug. 3, 2017), https://www.uspto.gov/sites/default/files/documents/PPAC_Transcript_20170803.pdf [https://perma.cc/E889-RW9X].

117. Johnson Letter, supra note 107 , at 8.

118. Author's analysis was based on the data generously provided by Unified Patents covering IPRs filed through April 2018: 949 out of 3,262 patents, or around 30\%.

119. Source on file with authors.

120. Source on file with authors.

121. See VISSER, supra note 74, at 246 points 1 and 2.

122. Id. at point 3 .

123. Source on file with authors.

124. Source on file with authors.

125. See VISSER, supra note 74, at 253. 
increases the likelihood of a finding of infringement. At the same time, the patent holder has an interest in a narrow claim construction when the validity of the patent is challenged.

German nullity (and until recently, U.S. IPR) proceedings use a different basis for claim construction than their infringement court counterparts. This can result in what is colloquially known as the "Angora cat": in infringement proceedings, the patent resembles a blow-dried fluffy cat, and in the invalidity proceedings, the same cat looks like a little wet rolled-up bundle. ${ }^{126}$ This is possible because, while the infringement court has to decide on the patent's scope of protection, the BPatG scrutinizes whether the patent satisfies the statutory requirements for patentability. In this system, a patent may be upheld and found infringed, although if the same claim construction had been applied in both proceedings, either no infringement would be found (based on the narrow claim construction) or the patent would be invalidated (based on the broad claim construction).

An example of the game-playing that different standards invite is provided by EP 1186 189, a European patent on telecommunication technology that was successfully asserted by patent holder IPCom against HTC in Germany. ${ }^{127}$ IPCom avoided the invalidation of EP 1186189 based on prior art by arguing in invalidity proceedings that the patent was limited to "to a system in which threshold value is assessed before access class." ${ }^{128}$ In the infringement proceedings, however, IPComm argued that the claims also covered "a system in which access class is assessed before threshold value." 129 This outcome is troubling, although there is no data beyond anecdote on the frequency with which a squeeze is successfully applied in parallel proceedings, ${ }^{130}$ let alone on its impact on the overall invalidation rate.

In the United States, until recently the courts and the PTAB also applied different standards to the construction of patent claims. The PTAB gave claim terms their "broadest reasonable interpretation" (BRI), but courts interpreted claims according to their ordinary and customary meanings, generally resulting in a narrower construction. ${ }^{131}$ In addition, claims are presumed valid in court,

126. Richard Vary, Presentation to UK Intellectual Property Office, Bifurcation: Bad for Business. Our Experience (Apr. 12, 2012), https://www.unitary-patent.eu/sites/ www.unitary-patent.eu/files/nokia_vary_bifufcation.pdf [https://perma.cc/7WYW-7U3G].

127. Id.

128. Id.

129. Id.

130. In data on German infringement and invalidity proceedings, a squeeze appears as a case in which infringement is found of a patent that is upheld in the invalidity proceedings. That is, without a direct comparison of claim construction in both proceedings, it is impossible to determine whether a different claim construction was (successfully) applied in both venues.

131. Dreyfuss, supra note 20, at 254. 
while at the PTO, no such presumption applies. The result was that, with respect to claim construction, the U.S. situation was essentially the opposite of the German one - a broad construction in the venue deciding validity, and a narrower construction in the venue deciding infringement. Because the U.S. system circumscribed the claim construction standard to a greater degree than the German system, the potential for opportunistic claiming was more limited.

\section{COORDINATION BETWEEN INFRINGEMENT AND INVALIDITY} DETERMINATIONS

Another feature of post-grant reviews that shapes how disputes are resolved is the coordination, or lack thereof, between the post-grant review (invalidity) and infringement proceedings during the "second window." Unlike "first window" challenges, during which concurrent infringement proceedings are rare, "second window" challenges are often prompted by allegations of infringement. When invalidity can be evaluated either in the "second window" post-grant patent review or by the court hearing the infringement issue, the potential for the post-grant patent administrative reviews to provide a cheaper, more expert alternative or substitute for district court litigation is great. Whether or not proceedings in the two venues actually work together, rather than at cross-purposes, depends crucially on whether or not the infringement court stays its proceedings in light of the patent's review by another tribunal. As described in the paragraphs that follow, in many jurisdictions in the United States, district courts tend to stay concurrent litigation pending the outcome of the IPR, whereas in Germany, the opposite is true. This Section explores the features and timing that leads to these outcomes.

The tight "interface" between U.S. IPR and U.S. district court proceedings represents one of the major changes to post-grant patent review ushered in by the AIA. Previously, the main form of post-grant patent review was in the form of PTO reexam proceedings, which had no time limits and could last up to nine years. ${ }^{132}$ AIA proceedings, in contrast, are subject to a strict timeline that limits how long an IPR can take. IPRs have to be filed within one year of a parallel litigation, and the PTO has to decide within three to six months whether to institute a review and complete the case within one year if it does. ${ }^{133}$ Although the PTAB has the ability to extend the time by six months, it rarely does so. ${ }^{134}$

132. See Matal, supra note 15 , at 614 .

133. 35 U.S.C. $\int 316($ a)(11) (2012) (the PTAB must determine whether to institute a trial within three months of the earlier of: the patent owner's preliminary response filing or the preliminary response due date, which is due within three months of the petition being filed).

134. Id. 
If there is parallel litigation, defendants usually request that the district court stay the proceedings. When a stay is requested, the court must consider a number of factors, including potential prejudice to the parties and the ability of the stay to simplify and streamline. Although staying the case means delaying a decision on the merits, the certainty afforded by the strict timeline of IPR, combined with the expert adjudication offered by the three-judge panel, and the chance that a number of the validity issues will be clarified, factors into the judge's decision. District courts grant stays in about half of the cases when an inter partes reexamination is pending, and they grant stays in around $80 \%$ of cases where and IPR has been instituted. ${ }^{135}$ If the court decides not to stay the case, the defendant is free to raise invalidity defenses in the litigation.

The interface between German nullity and infringement proceedings is different. Each issue is heard by a court that enters into a deliberative process that is not subject to time limits. The substitution effect is less of an issue as defendants cannot raise "invalidity defenses" to allegations of infringement. However, the failure to stay an infringement proceeding in favor of an invalidity proceeding can lead to a patent being found infringed and enforced, only to be subsequently ruled to have been wrongly issued in the first place. The likelihood of this scenario has potentially broad consequences-if the infringement court is unlikely to consider evidence of invalidity from a parallel forum, a defendant might think twice about spending the extra money required to bring a separate invalidity case. A patentee may feel more emboldened to assert a weak patent that has a strong infringement case. A study considered the prevalence and potential impact, of "invalid and infringed" German patents. ${ }^{136}$ Analyzing patents that were both enforced and challenged from $2000-2008$, the study found that $12 \%$ of awarded injunctions were based on patents that were later proven invalid. ${ }^{137}$

\section{U.S. (IPR), EUROPEAN (OPPOSITION) AND GERMAN (BPATG) SUBSTANTIVE AND PERFORMANCE-RELATED OUTCOMES}

Building upon the last part, this Part discusses how the design features of the post-grant review systems of the United States (IPR), European Opposition, and German (BPatG) revocation proceedings have translated into particular substantive and performance-related outcomes. For parties to postgrant patent reviews are generally most interested in what happens to the

135. See supra note 32 for calculation.

136. See Cremers et al., supra note 8989, at 219.

137. Id. 
patent. From a policymaker's perspective, however, several other yardsticks matter: what share of cases benefits from a merits-based decision? How long do they take? And to what extent do procedural factors create an uneven playing field, biasing the outcome in favor of one side or the other? Although the "substantive" outcome of validity rate receives most of the attention, the performance-related outcomes of adjudication rate, time to adjudication, and prejudice to the parties are arguably more important from an institutional design perspective. This Part reviews the substantive and performance-related outcomes of the three venues that have followed from the institutional design choices associated with each system.

\section{A. INVALIDITY RATES AND RATES OF ADJUDICATION}

IPRs have been subjected to fierce criticism because of their high rates of patent invalidation. But any invalidation rates must be understood in context, as the share of invalidated patents among all patents whose validity was challenged is the result of a number of selection mechanisms, both as imposed by the U.S. tribunal in the case of the institution decision and by the parties, through their decisions to settle. This means that IPR invalidity rates are neither representative of invalidity rates in the population of granted patents, nor those of litigated patents, nor even those of patents whose validity is challenged in post-grant reviews, but a further subset of all these groups.

Figure 4 depicts the selection of cases for adjudication in the three venues.

The German numbers shown in Fig. 4 are taken from a study based on data from 2000-2008, ${ }^{138}$ and the U.S. data is taken from the PTO's February 2018 update of IPR statistics. ${ }^{139}$ The EPO data is taken from the EPO website $^{140}$ with the exception of the $7 \%$ undecided rate, which represents settlements, withdrawals, and other situations where the opposition was dropped before a decision, and was obtained from the EPO directly. ${ }^{141}$

138. Id. at 219 .

139. See PTAB FEBRUARY STATISTICS, supra note 19.

140. See Annual Report 2017: Searches, examinations, oppositions, European Patent Office (January 22, 2018), https://www.epo.org/about-us/annual-reports-statistics/annual-report/ 2017/statistics/searches.html\#tab4 [https://perma.cc/9JJ6-YDRD].

141. As we note, U.S. data is available at the claim level, whereas the German data is only available at the patent level. Additionally, the authors obtained data directly from the EPO. 
Fig. 4: The Selection and Adjudication of Patents Challenged in Post-Grant Patent Opposition
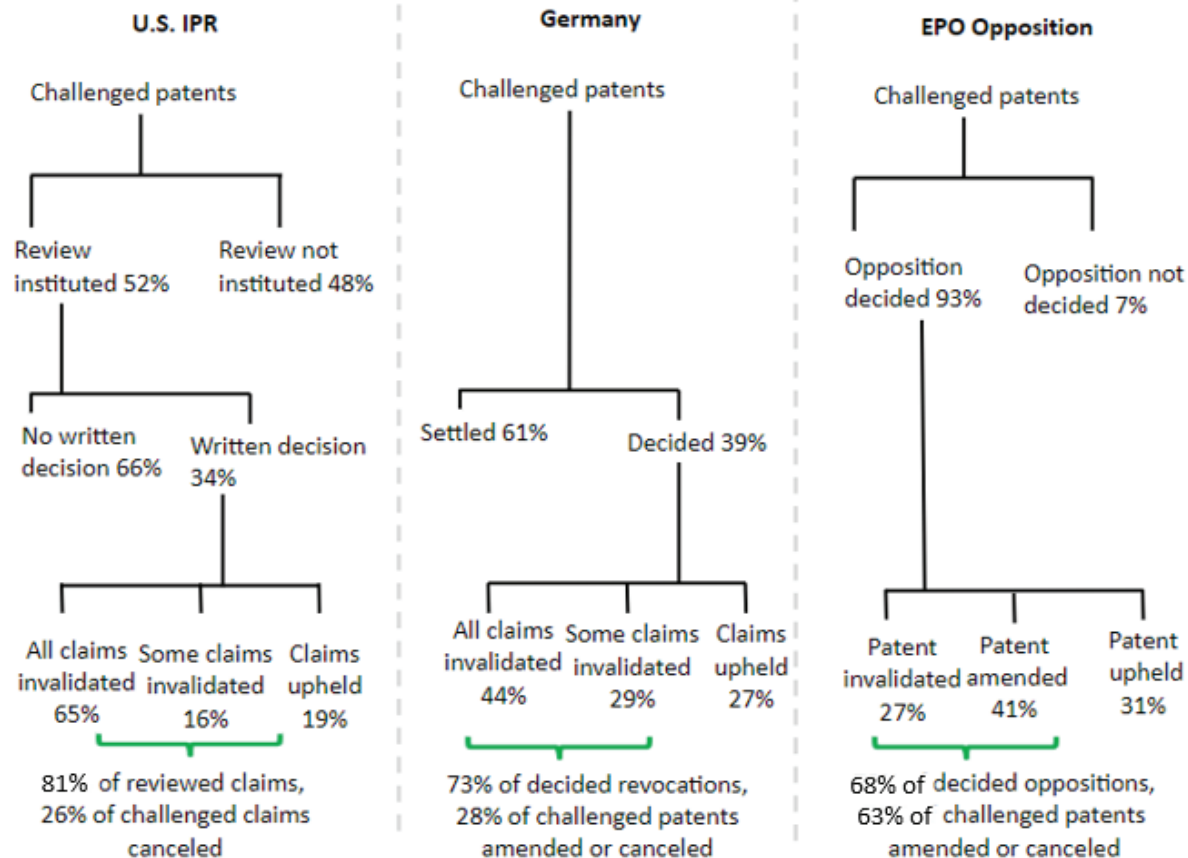

As Figure 4 shows, in the United States, 81\% of decided petitions have been determined to have one or more unpatentable claim, ${ }^{142}$ (as compared to a $43 \%$ invalidation rate in district court). ${ }^{143}$ In contrast, about $73 \%$ of patents challenged in the BPatG and $68 \%$ of patents subject to opposition decisions at the EPO are partially or fully revoked. ${ }^{144}$

These outcomes vary by industry. For example, within EPO opposition and German revocation proceedings, studies have reported that chemistry patents (which include pharmaceuticals), compared to patents in other industries, are most likely to be revoked or amended than patents in other industries (at a rate of $71 \%$ in the EPO, ${ }^{145}$ and $83 \%$ in German revocation). ${ }^{146}$

142. See PTAB FEBRUARY STATistics, supra note 19.

143. John R. Allison, Mark A. Lemley \& David L. Schwartz, Understanding the Realities of Modern Patent Litigation, 92 TEX. L. REV. 1769, 1801 (2014)

144. See Cremers et al., supra note 30 (the number $73 \%$ come from an earlier draft on file with the author).

145. Hall \& Harhoff, supra note 2, tbl.2.

146. Joachim Henkel \& Hans Zischka, Why Most Patents are Invalid - Extent, Reasons, and Potential Remedies of Patent Invalidity, tbl.4 (Sept. 29 2014) (unpublished manuscript) (based on data from 2000-2012) http://www.tim.wi.tum.de/fileadmin/w00bcy/www/ 
Based on our analysis, the opposite is true among U.S. IPRs. Among all instituted petitions with a final written decision between 2012 and 2016, around $60 \%$ of petitions some or all challenged claims of pharmaceutical patents were invalidated. ${ }^{147}$ In contrast, other technology fields such as software or electrical machinery have seen more than $80 \%$ of instituted petitions where at least some of the challenged claims were cancelled. ${ }^{148}$

A casual comparison of the invalidity rates suggests that, among the three venues, IPR results in the worst outcomes for patentees. However, the U.S. results are inflated by the selection effects introduced by the uniquely American pre-institution phase. When that factor and other settlement-based selection effects are removed, the U.S. invalidation rate shrinks relative to the others, with $26 \%$ of challenged patents (calculated based on petitions) in U.S. IPRs and $28 \%$ of challenged patents in German revocation being amended or cancelled. In the EPO, the cancellation or amendment rate is $63 \%$ of challenged patents. ${ }^{149}$

This EPO cancellation or amendment rate is higher, in turn, because of the EPO's high adjudication rate, a performance-based metric that is often overlooked but arguably just as important as the extent to which adjudicated patents are canceled or upheld. An adjudication-a merits-based decision by the court or administrator-clarifies the status of the claims and removes some, though not all, uncertainty from the dispute. On this metric, EPO opposition compares favorably: $93 \%$ of opposed patents at the EPO proceed to a decision on the merits, a far higher rate than U.S. IPR or German revocation. ${ }^{150}$ This high "decision" rate may be in part because "first window" evaluations often happen in the absence of the stakes and money of litigation that typically drive settlement. But it also may be because EPO opposition proceedings take into account and protect the interests of patentees, making them more willing to endure, rather than opting out (through settlement or revocation) of opposition. Over half of the time when a patent is partially or fully invalidated during opposition, $41 \%$ of the $68 \%$, or $60 \%$ of the patent is actually amended, not canceled. ${ }^{151}$ The distinction between partial cancellation and amendment is subtle but important: when patentees amend, they retain some level of control and are able to shape the contours of the patent claim, neither of which are true about partial or full invalidation.

Research/Publications/Henkel/Henkel_Zischka_2015-12_Patent_Validity.pdf [https://perma.cc/GWN5-GRBC].

147. Source on file with authors.

148. Source on file with authors.

149. See supra fig.3.

150. See infra III.B; see also supra fig.3.

151. Source on file with authors 
In contrast to the $93 \%$ of European oppositions that are decided, only $39 \%$ of German nullity cases are decided. ${ }^{152}$ The U.S. decision rate is somewhere in between: $48 \%$ of IPRs are not instituted (which essentially means that the PTO is confirming the claim's validity) and $34 \%$ of the $52 \%$ of the petitions that are instituted result in a written decision. ${ }^{153}$ This means, collectively, that about $66 \%$ of IPR petitions receive some sort of merits-based adjudication from the PTAB. In contrast, 61\% of German nullity cases are settled and do not receive any adjudication, representing a lost opportunity to clarify the status of the claims.

\section{B. Time to a Merits-DeCision}

Another important yet overlooked "outcome" metric for comparing the various forms of post grant patent review is how long it takes to get to a meritsbased decision. U.S. IPRs are efficient and reliable enough in terms of timing that U.S. district courts grant requests to stay the district court litigation in favor of a co-pending IPR in more than $80 \%$ of cases. ${ }^{154}$ As a result, a ruling from the PTO is available before the district court decides infringement, and in many cases moots or at informs courtroom adjudication. ${ }^{155}$ The opposite is true in Germany, where courts only stay their cases $10-15 \%$ of the time in favor of a revocation proceeding. ${ }^{156}$

Timing thus has consequences for case outcomes and, in the "second window," for the prevalence of invalid and infringed patents. It also influences the likelihood that parties will raise post-grant administrative challenges in the first place and whether such challenges will be heard. But timing also impacts "first window" reviews, because first window challenges cast a cloud over the validity of the issued patent. A user survey about opposition conducted by the EPO in 2016 showed that, while $70 \%$ of EPO users involved in opposition were either satisfied or very satisfied with opposition, they were much less satisfied, with a $37 \%$ satisfaction rate, with the relatively long duration of opposition proceedings at the EPO, which lasted an average of 26.1 months in 2015. ${ }^{157}$ Timing and user satisfaction in this way can serve as proxies for administrative efficiency.

152. See supra fig.3.

153. See supra fig.3.

154. See Love \& Ambwani, supra note 19, at 104 tbl.8.

155. See VirtualAgility Inc. v. Salesforce.com, Inc., 759 F.3d 1307, 1314 (Fed. Cir. 2014) (finding that a stay in a CBM case was warranted, in part, because the review could dispose of the entire litigation).

156. See Cremers et al., supra note 30, at 235 fig.2.

157. European Patent OfFice, EPO Quality RePort 2016 25-27, 31-33 (2016). 


\section{BifurCATION-RELATED OUtCOMES}

One final process outcome relates to the risk of error in the "second window" introduced by a lack of coordination between validity and infringement judgments. As described above, in Germany, the decision not to stay an infringement proceeding in favor of an invalidity proceeding can lead to a patent being found infringed and enforced, only to be subsequently ruled to have been wrongly issued in the first place. Across all German infringement and invalidity cases, the median length of the "injunction gap"-the time between a decision to enjoin and a decision on a patent's validity-is fourteen months. ${ }^{158}$ This means a plaintiff can have more than one year to enforce an injunction obtained based on the infringement decision, even if the infringed patent never should have been issued. Furthermore, the later revocation of the patent by the BPatG does not necessarily prevent enforcement of the infringement judgment. If the revocation is appealed, the remedy from infringement remains fully enforceable. If the patent is eventually fully invalidated, the infringer has the right to petition for restitution for the damage caused by the improperly granted remedy. ${ }^{159}$ But while restitution can involve compensation for losses incurred as a consequence of the injunction, it is unlikely to completely undo the harm suffered by the defendant. For example, if the injunction requires rendering accounts to a competitor, ${ }^{160}$ a claim for restitution cannot undo the harm caused by the leakage of information to a competitor. ${ }^{161}$

The possibility of an injunction gap impacts litigant behavior in several ways. First, defendants may be less likely to challenge a patent's validity because they can be subject to an injunction even if they successfully invalidate the patent. ${ }^{162}$ Second, defendants may be more likely to settle invalidity proceedings once infringement has been found to minimize the costs associated with the injunction gap. In particular, if both parties expect the invalidity challenge to be successful, the patentee has incentives to settle to avoid invalidation, and the defendant has incentives to stop the injunction gap and to avoid providing a public good to its competitors by invalidating the patent. Empirical evidence from Germany shows that most settlements of

158. See Cremers et al., supra note 30 at 234.

159. See Thomas Kühnen, A patent beld in a binding ruling to bave been infringed is subsequently revoked: what happens next?, 1 OJ EPO 56 (2009).

160. For example, in the case Dr. Johannes Heidenhain $\mathrm{GmbH}$ vs iC-Haus $\mathrm{GmbH}$, the court found infringement and $\mathrm{iC}-\mathrm{Haus}$ was forced to disclose sensitive business and financial information although the patent was later invalidated.

161. See Christoph Ann, Technische Richter in der Patentgerichtsbarkeit-ein Modell mit Perspektive?, in 50 JAHRE BUNDESPATENTGERICHT-FESTSCHRIFT ZUM 50-JÄHRIGEN BESTEHEN DES BuNDESPATENTGERICHTS 111-27 (2011).

162. See generally Cremers et al., supra note 3089. 
validity challenges indeed occur shortly after the judgment on infringement was handed down. ${ }^{163}$ Finally, plaintiffs may be more likely to enforce weak patents because of the prospect of some positive payoff during the injunction gap, even if the patent is eventually invalidated. ${ }^{164}$

Bifurcation in the United States and Germany raises additional procedural fairness issues. Dual proceedings, rather than a unified system, lead to greater costs and complications, which disproportionately impact smaller parties. Empirical evidence from Germany shows that, in particular, smaller and more resource-constrained firms as well as foreign firms, for whom litigation in Germany is more costly, are less likely to challenge validity in parallel proceedings. ${ }^{165}$ It would be worthwhile interrogating the extent to which this is the case in the U.S. as well. However, the fact that multiple defendants have the ability to support an IPR challenge, such as private ordering through groups like Unified Patents, would likely, at least partially, offset the asymmetry. Inversely, it would be worthwhile investigating the extent to which small plaintiffs are systematically disadvantaged by the extra cost and complexity under bifurcation.

\section{POLICY IMPLICATIONS}

From the previous Part's exploration of several performance-based metrics, including adjudication rate, speed, and procedural fairness, several observations can be made about the relative strengths and weaknesses of each venue. European opposition enjoys the highest share of merits-based adjudication; its amendment practice and consolidation of claims also feel more balanced by protecting the patentee's interests even while the patent is being challenged. However, the relatively long pendency of oppositions (around twenty-four months) appears to present challenges for both the patentee and petitioners. ${ }^{166}$

The United States outperforms the EPO on timing and provides a merits decision of sorts through the institution decision within six months of the petition. ${ }^{167}$ This supports a rate of adjudication that, while less than that of EPO opposition proceedings, still far outstrips German nullity. However, amendment practice is still quite immature in the United States, with only the patent to lose and seemingly little for the patentee to gain in IPR because patent's survival provides no official buffer from subsequent challenges.

163. Id. at tbl.A5.

164. See id.

165. Id.

166. See supra fig.2.

167. Source on file with authors. 
In Germany, the playing field is tilted in the opposite direction-the speed of the infringement court prevents invalidity defenses, even strong ones, from mattering too much. Much of this stems from the relatively slow nullity process combined with a strong presumption of validity applied by the regional courts deciding on infringement, which limits stays. ${ }^{168}$

\section{A. THE U.S.}

In the United States, thus far, the high rate of IPR invalidations has caused great concern. But until now, much of this anxiety has been generated in the absence of a full description regarding how cases are selected for adjudication and without the benefit of knowing parallel experiences. The information presented in this Article should give some comfort to those who are worried about post-grant patent reviews undermining the patent system. The IPR system is set up to review patents that most likely contain invalid claims, not patents in general. Its rates of invalidation, when placed in their proper context, are within range of its counterpart jurisdictions of the EPO and German, which have a reputation for producing "high quality" patents. As Rochelle Dreyfuss said: "many claims deserve to die;" 169 conversely, few claims are worth the expense and trouble of killing. The popularity of the IPR venue and the high rate of cases that receive a decision on the merits in the form of at least an institution decision indicate that it is successfully addressing the public goods nature of patent invalidity and serving the purpose of clarifying the status of questionable claims. However, the selection process does not necessarily imply that the IPR invalidity rate is applicable to issued, or even litigated, patents.

Yet the controversies surrounding post grant patent reviews underscore that it is, at best, a backend process for catching the errors that would have been better off being caught during the frontend patent examination process. Greater attention to preventing patents from being improperly issued in the first place is worthwhile. For example, as one of us has previously found, the PTAB relies upon non-patent literature to a greater degree in IPRs than the examiner corps does in examination. ${ }^{170}$ Understanding further why this is the case could provide key insights regarding how to improve pre-grant examination procedures.

In addition, the question of how to make the playing field more level, both as to the rights of patentees and to smaller parties in general, given the high costs of adjudicating in two venues, is worth considering further. As described

168. See supra Section III.A.

169. Dreyfuss, supra note 20, at 255.

170. Colleen Chien, Comparative Patent Quality, 50 ARIZ. ST. L.J. 71 (2018). 
earlier, and more extensively below, reconsideration of amendments and serial petitions, could address some of these concerns.

Though unique, the institution decision of IPR is a source of early clarification to the parties, increasing the chance of a merits-based decision. This point should be kept in mind as any changes to the institution decision are considered. Expanding amendment practice, could cut the other way, introducing uncertainty as to the validity and boundaries of the evolving claims. However, further investigations into how to accommodate amendments while preserving IPR's operational efficiency, which is key to supporting IPR's substitutive effect, should be pursued. As the EPO's experience shows, balancing a short pendency with the right to amend is challenging. ${ }^{171}$

The high infringement court stay rate in the U.S., particularly when contrasted with a much lower stay rate in Germany, is a testament to the reliability and high regard of the courts for the PTAB in the United States. These findings also highlight the importance of the decision to stay infringement proceedings in view of invalidity proceedings. In the German system, where stays are rare, $12 \%$ of infringed patents are later found to be invalid, creating an injunction gap that lasts for a median of thirteen and a half months. The U.S. system's timing safeguards, in contrast, minimize the injunction gap.

A final issue for the United States pertains to the balance of rights of patentees in the face of serial challenges. In Europe, a fixed opposition period encourages all oppositions challenging a patent's validity to be grouped together in the procedure. Even when interventions of assumed infringers are filed during pending opposition, ${ }^{172}$ the interveners join the existing opposition procedure. In practice, such consolidation is much harder in "second window" review systems. However, it may be worth exploring ways to encourage joining existing IPRs without delaying the proceedings, perhaps by PTAB teams adding a "fourth" member to offset the additional burden introduced by subsequent challengers and keep the proceeding on schedule.

In the EU, the patentee has the option of filing limitation and revocation requests ${ }^{173}$ at any time during the life of a patent. When such requests are filed in parallel to a pending opposition, they take priority, and the opposition procedure is de facto stayed. This means that a patent proprietor facing an opposition can limit the scope of his patent or request its revocation, rendering the opposition superfluous or meaningless. While very few revocation requests

171. See infra Section V.B.

172. See EPC art. 105.

173. See id. at art. 105(a). A patentee can also request the revocation of his or her patent under Article 105(a). However, this option is far less used than limitation. 
are filed yearly, limitation is more frequently requested by patentees because it is a cheap way to centrally fine tune the granted patent even after closure of the opposition period. ${ }^{174}$

The United States does provide for this sort of tuning to some degree through the reissue process; however, reissues tend to be used infrequently. Nevertheless, it should be acknowledged that EPO limitation requests may be perceived by third parties as an unfair weapon in the patent proprietor's hands for two reasons: first, after the first window, a third party must go to individual courts in Europe in order to challenge a patent; and second, a patentee, who can claim broadly in examination, could later tailor the claims' scope to cover their competitors' production or the actual market needs. ${ }^{175}$

\section{B. GERMANY AND THE EPO}

Though this Article declines to provide normative recommendations for EPO and Germany, because they are not the focus of this article. We do make some suggestions, grounded in the observation that no system, no matter how old, is perfect, and that there are often tradeoffs associated with features that, viewed in isolation, might otherwise seem optimal. For example, the speed of German infringement adjudications, while commendable in its own light, has contributed to the "invalid but infringed gap." The thoroughness of the EPO process, which allows for amendments and the consolidation of multiple challenges, also does contribute to its relatively slow pace, which users have complained about.

To deal with the invalid but infringed gap, we encourage further consideration of one mechanism for balancing competing interests. Building on previous work one of us has done to advance the idea of tailored injunctions, judges may be able to craft "flexible" injunctions that will make it easier to grant stays without harming the patentee's legitimate interests. ${ }^{176}$ For example, courts could condition the stay on the party's voluntary estoppel if the petitioner is not a party to the lawsuit or as justice otherwise requires. ${ }^{177}$ And when there is not a stay, courts can take measures to minimize the harms associated with an incorrect injunction through bonding, delaying

174. Source on file with authors.

175. See VISSER, supra note 74, at Article 105(a). This feature of limitations resembles U.S. "continuation" practice. See Mark Lemley \& Kim Moore, Ending Abuse of Patent Continuations, 84 B.U. L. REV. 63, 66-67 (2003).

176. For an overview of the related concept of tailored injunctions, see Colleen V. Chien \& Mark A. Lemley, Patent Holdup, the ITC, and the Public Interest, 98 CORnelL L. REV. 1, 32-34 (2012) and Colleen Chien \& Eric Schulman, Patent Semicomparables, 25 TEX. INTELL. PROP. L.J. 215, 247-250 (2018).

177. We thank David Schwartz for making this point to us. 
implementation of injunctions, and other such measures. This is an aspect of bifurcated systems that deserves further analysis.

On that note, it is useful to consider the types of process improvement which should be come to seen, not as defects, but part of a normal recalibration. In July 2016, after consultation with the user community, the EPO significantly reformed its opposition procedure to reduce pendency to fifteen months by 2020. The EPO introduced this transition period in order to ensure that the right to be heard and the ability of the patentees to amend their patents during opposition before the first instance would be preserved, even in the shortened time frame. ${ }^{178}$ The EPO's reforms also concentrated opposition cases on a central pool of experienced examiners specializing in opposition for a third of their time and ensured that former members of the examining division would, as a rule, no longer be part of the opposition division after previous procedures had elicited concerns about impartiality. ${ }^{179}$

Most of the new features of this new opposition procedure impact "straightforward" cases. ${ }^{180}$ More complex oppositions with more than one opponent, for example, are not affected by the streamlining measures because the complexity of these cases required more time for the parties and the opposition division. During this streamlining effort, the EPO implemented three main lines of change. First, requests for time limit extensions, which used to be generously granted, are now only granted in exceptional cases (for example, when long laboratory tests are necessary). ${ }^{181}$ Second, the EPO implemented the principle of parallel proceedings wherever possible. ${ }^{182}$ For example, after receiving the patentee's reply to the notice of opposition, the reply of the patentee is dispatched at the same time to the opponent(s) and to the division which starts to study the case. ${ }^{183}$ In the past, it was usual to limit other parties' counterarguments to the patentee's submission to four months. Third, the EPO rationalized and harmonized its opposition decision process. ${ }^{184}$ Apart from the exceptional cases for which the division can take an immediate decision without hearing, the opposition division will issue only one intermediate office action, which is the summons to the oral proceedings. ${ }^{185}$ The date of the oral proceedings is set at least six months after issuance of the

178. See European Patent Office, supra note 73.

179. Letter from Benoît Battistelli, President, European Patent Office, to Administrative Council: Reorganisation of DG1 and DG2; consolidation and streamlining of the Office structures (June 9, 2017).

180. Source on file with authors.

181. Source on file with authors.

182. Source on file with authors.

183. Source on file with authors.

184. Source on file with authors.

185. Source on file with authors. 
summons, and the deadline for filing last submissions is set two months before the date of the oral proceedings. ${ }^{186}$ This new procedure, it is hoped, will enable the EPO to reduce the pendency for the straightforward cases down to fifteen months instead of two years or more.

\section{CONCLUSION}

The common refrain of this Article-that the details matter-endows agencies with both the responsibility of attending to these details and the power to make significant improvements often of their own accord. In the case of IPR, given the sensitivity of the post-grant process to small design variables, caution should be applied to making changes to a procedure that is working more successfully than its predecessor, inter partes reexamination and, arguably, more successfully than the German system, with its lower settlement rate and reduced chance of invalid and infringed outcomes. In particular, to ensure that IPRs continue to provide an efficient, effective alternative to litigation, IPR proceedings should continue to be predictable, timely, and clear. While striking the right balance is never an easy task, comparative experiences can provide inspiration and caution along the way.

186. Source on file with authors. 